\begin{tabular}{|l|l|l||}
\hline \multicolumn{2}{|c|}{ PublisherInfo } \\
\hline \hline PublisherName & $:$ & BioMed Central \\
\hline \hline PublisherLocation & $:$ & London \\
\hline \hline PublisherImprintName & $:$ & BioMed Central \\
\hline \hline
\end{tabular}

\title{
Articles selected by Faculty of 1000: single-cell neuronal expression analysis; array analysis of chick hair cells; coiled-coil protein arrays; high-throughput identification of plasmodesmata- interacting proteins; multicompenent therapeutics
}

\begin{tabular}{|l|c||l||}
\hline \multicolumn{2}{|c|}{ ArticleInfo } \\
\hline \hline ArticleID & $:$ & 3469 \\
\hline \hline ArticleDOI & $:$ & $10.1186 /$ gb-2003-4-8-334 \\
\hline \hline ArticleCitationID & $:$ & 334 \\
\hline \hline ArticleSequenceNumber & $:$ & 13 \\
\hline \hline ArticleCategory & $:$ & Paper report \\
\hline ArticleFirstPage & $:$ & 1 \\
\hline \hline ArticleLastPage & $:$ & 3 \\
\hline \hline & $:$ & RegistrationDate : 2003-7-18 \\
ArticleHistory & $:$ OnlineDate 2003-7-18 \\
\hline \hline
\end{tabular}




\begin{tabular}{|l|l|l||}
\hline ArticleCopyright & $:$ & BioMed Central Ltd2003 \\
\hline \hline ArticleGrants & $:$ & \\
\hline \hline ArticleContext & $:$ & 130594488 \\
\hline
\end{tabular}

The Author(s)

\section{Summary}

A selection of evaluations from Faculty of $\mathbf{1 0 0 0}$ covering single-cell neuronal expression analysis, array analysis of chick hair cells, coiled-coil protein arrays, high-throughput identification of plasmodesmata-interacting proteins and multicompenent therapeutics.

\section{Single-cell neuronal expression analysis}

Single-cell transcriptional analysis of neuronal progenitors. Tietjen I, Rihel JM, Cao Y, Koentges G, Zakhary L, Dulac C. Neuron 2003, 38:161-175.

For the Faculty of 1000 evaluation of this article please see: http://genomebiology.com/reports/F1000/ gb-2003-4-8-334.asp\#Tietjen

\section{Array analysis of chick hair cells}

Gene expression differences in quiescent versus regenerating hair cells of avian sensory epithelia: implications for human hearing and balance disorders. Hawkins RD, Bashiardes S, Helms CA, Hu L, Saccone NL, Warchol ME, Lovett M. Hum Mol Genet 2003, 12:1261-1272.

For the Faculty of 1000 evaluation of this article please see: http://genomebiology.com/reports/F1000/ gb-2003-4-8-334.asp\#Hawkins

\section{Coiled-coil protein arrays}

Comprehensive identification of human bZIP interactions with coiled-coil arrays. Newman JR, Keating AE. Science 2003, 300:2097-2101. 
For the Faculty of 1000 evaluation of this article please see: http://genomebiology.com/reports/F1000/ gb-2003-4-8-334.asp\#Newman

\section{High-throughput identification of plasmodesmata-interacting proteins}

High-throughput viral expression of cDNA-green fluorescent protein fusions reveals novel subcellular addresses and identifies unique proteins that interact with plasmodesmata. Escobar NM, Haupt S, Thow G, Boevink P, Chapman S, Oparka K. Plant Cell 2003, 15:1507-1523.

For the Faculty of 1000 evaluation of this article please see: http://genomebiology.com/reports/F1000/ gb-2003-4-8-334.asp\#Escobar

\section{Multicompenent therapeutics}

Systematic discovery of multicomponent therapeutics. Borisy AA, Elliott PJ, Hurst NW, Lee MS, Lehar J, Price ER, Serbedzija G, Zimmermann GR, Foley MA, Stockwell BR, Keith CT. Proc Natl Acad Sci USA 2003, 100:7977-7982.

For the Faculty of 1000 evaluation of this article please see: http://genomebiology.com/reports/F1000/ gb-2003-4-8-334.asp\#Borisy

This PDF file was created after publication. 